\title{
Radionuclide Content and Risk Assessment of some Environmental Samples from Gold Mines at Mokuro-Ile-Ife, Osun State, Nigeria
}

\author{
Oyebamiji Oyedele Oketayo $^{1 *}$, Muyiwa Joshua Adeleke ${ }^{1}$ and Olusola S. Ayanda ${ }^{2}$ \\ ${ }^{1}$ Department of Physics, Federal University Oye Ekiti \\ Oye-Ekiti, Ekiti State, Nigeria \\ ${ }^{2}$ Department of Chemistry, Federal University Oye Ekiti \\ Oye-Ekiti, Ekiti State, Nigeria \\ *Corresponding author's email: oyebamiji.oketayo [AT] fuoye.edu.ng
}

\begin{abstract}
Mining and processing of natural resources has being in existence from the beginning of early years with little or no consideration to the possible radiation and contamination being posed into the environment. Using NaI (TI) gamma ray spectrometer, the activity concentration of naturally occurring radionuclides were determined in soil, rock and water samples from Mokuro gold mines in Osun State, Nigeria. The average activity concentrations of ${ }^{40} \mathrm{~K}$, ${ }^{238} \mathrm{U}$ and ${ }^{232} \mathrm{Th}$ in soil samples were $362.39 \pm 83.88,21.42 \pm 6.68$ and $17.99 \pm 6.68 \mathrm{~Bq} / \mathrm{kg}$ while in rock samples were $412.62 \pm 91.18,24.61 \pm 8.58$ and $19.40 \pm 6.76 \mathrm{~Bq} / \mathrm{kg}$ respectively. For water samples, the mean activity concentrations were in the range of $8.65 \pm 4.16 \mathrm{~Bq} / \mathrm{L}, 7.71 \pm 3.42 \mathrm{~Bq} / \mathrm{L}$, and $102.44 \pm 30.50 \mathrm{~Bq} / \mathrm{L}$ respectively. The annual effective dose contributed by ${ }^{238} \mathrm{U},{ }^{232} \mathrm{Th}$ and ${ }^{40} \mathrm{~K}$ varied from $0.84 \mathrm{mSv} / \mathrm{y}$ to $0.93 \mathrm{mSv} / \mathrm{y}$ with an average value $0.88 \mathrm{mSv} / \mathrm{y}$ while ${ }^{232} \mathrm{Th}$ varied from $0.018 \mathrm{mSv} / \mathrm{y}$ to $0.020 \mathrm{mSv} / \mathrm{y}$ with average value $0.019 \mathrm{mSv} / \mathrm{y}$ and ${ }^{40} \mathrm{~K}$ varied from $0.22 \mathrm{mSv} / \mathrm{y}$ to 0.25 $\mathrm{mSv} / \mathrm{y}$ with an average value $0.233 \mathrm{mSv} / \mathrm{y}$. The ${ }^{238} \mathrm{U}$ contribution to the Annual Effective Dose was very high compared with ${ }^{232}$ Th and ${ }^{40} \mathrm{~K} .$. The calculated mean of absorbed dose (ADR), Annual Effective Dose (AED), Radium equivalent dose rate (Ra eq), Internal and External Hazard Indices in the study area were less than the world averages and the limit recommended by ICRP for all water samples. The data obtained provided the baseline concentration and also indicated that continuous exploration could lead to contamination and eventually be hazardous.
\end{abstract}

Keywords--- Radionuclide content, environmental samples, gold mines

\section{INTRODUCTION}

Mining and processing of natural resources has being in existence from the beginning of early centuries. It serves as job opportunity and help man to sustain his environment. Despite these, such activities could also lead to problems like deforestation, loss of nutrients in soil, deposition of tailings (which contain high concentrations of natural radionuclides) in the surroundings which is of great health concern to the people. (Isinkaye, 2013; Ferreira da Silva et al., 2004). Miners are exposed to radiation by direct inhalation of suspended dust particles in air or by indirect ingestion through the consumption of food crops grown on tailing enriched soil (UNSCEAR, 2000).

Human exposure to natural radiation can be internal or external. The major contribution to external exposure comes from gamma-emitting radionuclides available in trace amounts in soil and sediment from ${ }^{328} \mathrm{U},{ }^{232} \mathrm{Th}$ decay series and ${ }^{40} \mathrm{~K}$. Internal exposures occur from the intake of terrestrial (land) radionuclides by inhalation and ingestion. The most occurring components of exposure to inhalation are the short-lived decay products of radon and the doses from ingestion are due to ${ }^{238} \mathrm{U}$ and ${ }^{232} \mathrm{Th}$ decay series and ${ }^{40} \mathrm{~K}$ present in food and water. IAEA in 1996 estimated that $80 \%$ of dose contributions in the environment are derived from the natural radionuclides while the remaining $20 \%$ is from artificial radionuclides like medical purposes (x-ray) and nuclear processes. The natural radionuclides of major concern in terrestrial (land) environment are mainly potassium ${ }^{40} \mathrm{~K}$, uranium ${ }^{238} \mathrm{U}$, thorium ${ }^{232} \mathrm{Th}$ (IAEA in 1996). In this study, the activity concentration of naturally occurring radionuclides ${ }^{40} \mathrm{~K},{ }^{238} \mathrm{U}$ and ${ }^{232} \mathrm{Th}$ were determined in soil, rock and water samples from Mokuro gold mines in Osun State, Nigeria. The mean absorbed dose (ADR), Annual Effective Dose (AED), Radium equivalent dose rate $\left(\mathrm{Ra}_{\mathrm{eq}}\right)$, Internal and External Hazard Indices were also estimated.

\section{MATERIALS AND METHODS}

2.1 Sample collection

The study area is located at Mokuro town, Atakumosa West Local Government, Osun State, Nigeria which lies within latitude $7^{\circ} 30^{\prime \prime} \mathrm{N}$ and $7^{\circ} 34^{\prime} \mathrm{N}$ and longitude $4^{\circ} 36^{\prime} \mathrm{E}$ and $4^{\circ} 42^{\prime} \mathrm{E}$. Eighteen samples (18): 3 soil samples and their respective 
tailings from different pits (at a depth of 4-5 m) were collected within the region. Similarly, a total of six rock samples were collected using clean hand gloves and later packed in separate nylon made of non-radioactive material. Drinking water samples were also collected from three different sources within the mining environment. Each sample was sealed and labeled to avoid contamination.

\subsection{Sample preparation}

The samples collected were taken to the Department of Geology Laboratory, Obafemi Awolowo University where the rock samples were been grounded into fine powder using sledge hammer and sieved separately using mesh sieve to a tiny particle. Each soil sample was air dried and sieved with $2 \mathrm{~mm}$ mesh sieve. The collected water samples were left overnight in polyethylene container to allow settling of any suspended solid materials and a clear supernatant was separated by decantation. The clear water was acidified using concentrated mineral acids, to prevent any loss of radium-isotope around the container walls and to avoid growth of micro-organisms (Tchokossa, 2006).

These samples were taken to Centre for Energy Research and Development (CERD), Obafemi Awolowo University, IleIfe, Osun State Nigeria where each sample was put in a plastic container, sealed with paper cell tape and kept for more than twenty-eight days so as to reach secular equilibrium after which each container was placed directly on top of the detector for analysis. The survey meter was used to determine whether the samples were radioactive or not (for safety).

\subsection{Sample analysis}

The concentration of elements of interest in the prepared samples were investigated using gamma spectrometer of 7.6 $\mathrm{x} 7.6$ $\mathrm{cm} \mathrm{NaI}$ (TI) scintillator detector (model Bircom) crystal placed in a lead castle. The detector was properly connected to a multi-channel analyzer (MCA). A well calibrated standard source supplied by the IAEA available at the CERD was used for energy and efficiency calibrations and connected for the counting losses due to coincidence summing effects. Counting was done for $3600 \mathrm{sec}$. (10 hours). This time was enough for the detector to collect a spectrum with the peaks of interest clearly shown and clearly distinguished. The energy and efficiency of the gamma spectroscopy system were made to quantify radionuclides present in a sample.

\subsection{Determination of activity concentrations $\left(\mathrm{A}_{\mathrm{c}}\right)$}

The activity concentrations of ${ }^{238} \mathrm{U},{ }^{232} \mathrm{Th}$, and ${ }^{40} \mathrm{~K}$ were determined using the equation below

$$
\frac{N}{\varepsilon_{f} P_{\gamma} t_{s} m K}
$$

Where $N=$ the corrected net peak area of the corresponding full-energy peak

$$
\begin{aligned}
& \mathrm{N}=\mathrm{N}_{\mathrm{S}}-\mathrm{N}_{\mathrm{B}} \\
& N_{S}=\text { the net peak area in the spectrum of the sample } \\
& N_{B}=\text { the corresponding net peak area in the background spectrum } \\
& \varepsilon_{f}=\text { the efficiency at photo peak energy } \\
& t_{s}=\text { the live time of the sample spectrum collection in seconds } \\
& m=\text { the mass (kg) of the measured sample } \\
& P_{\gamma}=\text { the gamma-ray emission probability corresponding to the peak energy } \\
& K=\text { the correction factor for nuclide decay from the time of sampling to counting }
\end{aligned}
$$

The absorbed dose rate $\left(\mathrm{nGyh}^{-1}\right)$ from the samples was calculated from the activity concentration of the relevant radionuclide using the equation below (UNSCEAR, 2000) as

$D\left(n G y h^{-1}\right)=0.0417 A_{k}+0.428 A_{u}+0.666 A_{T h}$

Where $A_{k}, A_{u}$ and $A_{T h}$ are the activity concentrations of ${ }^{40} \mathrm{~K},{ }^{238} \mathrm{U}$, and ${ }^{232} \mathrm{Th}$

The Annual Effective Dose Rate (AEDR) and Radium Equivalent Dose Rate $\left(\mathrm{Ra}_{\mathrm{eq}}\right)$ were also estimated using

$\left.A E D R\left(\frac{m s V}{y r}\right)=D\left(n G y h^{-1}\right) \times 8760 h y^{-1}\right) \times 0.2 \times 0.7\left(s V G y^{-1}\right) \times 10^{-6}$

Where $\mathrm{D}=$ Dose rate $0.7\left(\mathrm{sVGy}^{-1}\right)$ is a conversion factor, AEDR $(\mathrm{msV} / \mathrm{yr})=\mathrm{D} \times 1.21 \times 10^{-3}$ for outdoor and $\mathrm{D} \times 4.91 \mathrm{x}$ $10^{-3}$ for indoor in $(\mathrm{Bq} / \mathrm{kg})$ and

$R a_{e q}=A u+1.43 A_{T h}+0.077 A_{k} \quad$ (Beratka \& Mathew, 1985) ---------------------(3) respectively. 
The Annual Effective Dose (AED) was calculated as

$\mathrm{AED}=\Sigma \mathrm{I}_{\mathrm{i}} \times 365 \times \mathrm{D}_{\mathrm{i}}$, in $(\mu \mathrm{s} \mathrm{V} / \mathrm{yr})$

where $\mathrm{I}_{i}$ is the daily intakes of radionuclide in $\left(\mathrm{Bqd}^{-1}\right)$ and $\mathrm{D}_{i}$ is the ingestion dose coefficient $\left(\mathrm{SvBq}^{-1}\right)$.

\subsection{Internal and external radiation indices}

The decay of naturally occurring radionuclides in soils produces an external radiation field to which all human beings are exposed. This was computed using the equation

$$
\mathrm{H}_{\mathrm{ex}}=\mathrm{A}_{\mathrm{u}} / 370+\mathrm{A}_{\mathrm{Th}} / 259+\mathrm{A}_{\mathrm{k}} / 4810 \text {. }
$$

while the internal radiation index $\left(\mathrm{H}_{\mathrm{in}}\right)$ was calculated using

$$
\mathrm{H}_{\mathrm{in}}=\mathrm{A}_{\mathrm{u}} / 185+\mathrm{A}_{\mathrm{Th}} / 259+\mathrm{A}_{\mathrm{k}} / 4810
$$

\section{RESULTS AND DISCUSSION}

Table 1 and 2 depict the annual effective dose rate, radium equivalent dose as well as the Internal and external radiation indices of ${ }^{40} \mathrm{~K},{ }^{238} \mathrm{U}$ and ${ }^{232} \mathrm{Th}$ for the observed radionuclides in the soil and rock samples respectively. Table 3 gives the summary of the dose rate and annual effective dose in water samples.

Table1: Dose rate, annual effective dose rate, radium equivalent dose, internal and external radiation indices of ${ }^{40} \mathrm{~K}$, ${ }^{238} \mathrm{U}$ and ${ }^{232} \mathrm{Th}$ in soil (ore and tailings) samples

\begin{tabular}{lllllll}
\hline Sample ID & $\begin{array}{l}\text { Dose Rate } \\
(\mathrm{nGy} / \mathrm{hr})\end{array}$ & $\begin{array}{l}\text { Annual Effective } \\
\text { Dose }(\mathrm{mSv} / \mathrm{hr}) \\
(\text { outdoor })\end{array}$ & $\begin{array}{l}\text { Annual Effective } \\
\text { Dose }(\mathrm{mSv} / \mathrm{hr}) \\
\text { (indoor) }\end{array}$ & $\begin{array}{l}\text { Radium } \\
\text { equivalent } \\
\text { dose }\left(\mathrm{Ra}_{\mathrm{eq}}\right) \\
(\mathrm{Bq} / \mathrm{Kg})\end{array}$ & $\mathrm{H}_{\mathrm{ex}}$ & $\mathrm{H}_{\mathrm{in}}$ \\
& & & & & & \\
\hline Ore 1 & 42.50 & 0.051 & 0.208 & 87.3289 & 0.2359 & 0.3012 \\
Ore 2 & 33.19 & 0.040 & 0.163 & 68.4624 & 0.1849 & 0.2386 \\
Ore 3 & 38.31 & 0.046 & 0.188 & 78.5550 & 0.2122 & 0.2694 \\
Tailings 1 & 36.68 & 0.044 & 0.180 & 76.0377 & 0.2054 & 0.2687 \\
Tailings 2 & 41.11 & 0.049 & 0.201 & 84.5609 & 0.2284 & 0.2896 \\
Tailings 3 & 29.48 & 0.036 & 0.145 & 60.7179 & 0.1634 & 0.2105 \\
\hline Mean & 36.88 & 0.044 & 0.180 & 75.9438 & 0.2050 & 0.2128
\end{tabular}

Table 2: Dose rate, annual effective dose rate, radium equivalent dose, internal and external radiation indices of ${ }^{40} \mathrm{~K},{ }^{238} \mathrm{U}$

\begin{tabular}{|c|c|c|c|c|c|c|c|c|}
\hline $\begin{array}{l}\text { Sample } \\
\text { ID }\end{array}$ & $\begin{array}{l}\text { Dose Rate } \\
(\mathrm{nGy} / \mathrm{hr})\end{array}$ & $\begin{array}{l}\text { Annual } \\
\text { Effective } \\
\text { (mSv/hr) } \\
\text { (outdoor) }\end{array}$ & Dose & $\begin{array}{l}\text { Annual } \\
\text { Effective } \\
\text { (mSv/hr) } \\
\quad \text { (indoor) }\end{array}$ & Dose & $\begin{array}{l}\text { Radium } \\
\text { equivalent dose } \\
\left(\mathrm{Ra}_{\mathrm{eq}}\right) \\
(\mathrm{Bq} / \mathrm{Kg}\end{array}$ & $\mathrm{H}_{\mathrm{ex}}$ & $\mathrm{H}_{\text {in }}$ \\
\hline${ }^{40} \mathrm{~K}$ & 41.03 & 0.049 & & 0.201 & & 84.3523 & 0.2278 & 0.2663 \\
\hline${ }^{238} \mathrm{U}$ & 41.07 & 0.049 & & 0.202 & & 84.8756 & 0.2292 & 0.2939 \\
\hline${ }^{232} \mathrm{Th}$ & 40.27 & 0.048 & & 0.197 & & 83.1827 & 0.2247 & 0.2910 \\
\hline Mean & 40.79 & 0.048 & & 0.200 & & 84.1369 & 0.2272 & 0.2937 \\
\hline
\end{tabular}
and ${ }^{232} \mathrm{Th}$ in rock samples

Table 3: Dose rate and annual effective dose of water samples

\begin{tabular}{llc}
\hline Intake per person & $\begin{array}{l}\text { Dose Rate } \\
(\mathrm{nGy} / \mathrm{hr})\end{array}$ & $\begin{array}{c}\text { Annual effective dose } \\
\text { Ingestion dose coefficient (msV/bq) }(1 \mathrm{CRP}, 68,1994)\end{array}$
\end{tabular}

\begin{tabular}{lllll}
\hline Sample ID & $\begin{array}{l}\text { Dose Rate } \\
(\mathrm{nGy} / \mathrm{hr})\end{array}$ & $\begin{array}{c}6.2 \times 10^{-9} \\
\left(s V . B q^{-1}\right) \text { for }{ }^{40} \mathrm{~K}\end{array}$ & $\begin{array}{c}2.8 \times 10^{-7} \\
\left(s V . B q^{-1}\right) \text { for }{ }^{238} U\end{array}$ & $\begin{array}{c}6.9 \times 10^{-9} \\
\left(s V . B q^{-1}\right) \text { for }{ }^{232} \mathrm{Th}\end{array}$ \\
W/S A & 13.89 & 0.250 & 0.930 & 0.020 \\
W/S B & 13.05 & 0.220 & 0.840 & 0.018 \\
W/S C & 13.09 & 0.230 & 0.880 & 0.019 \\
\hline Mean & 13.34 & 0.233 & 0.883 & 0.019 \\
\hline
\end{tabular}


In soil samples, the mean specific activity of ${ }^{40} \mathrm{~K}$ ranged from $229.11 \mathrm{~Bq} / \mathrm{kg}$ to $442.93 \mathrm{~Bq} / \mathrm{kg}$ while ${ }^{238} \mathrm{U}$ ranged from 17.20 $\mathrm{Bq} / \mathrm{kg}$ to $24.18 \mathrm{~Bq} / \mathrm{kg}$. It was in the order ${ }^{40} \mathrm{~K}>{ }^{238} \mathrm{U}>{ }^{232} \mathrm{Th}$. The mean dose rate $(\mu \mathrm{s} \mathrm{V} / \mathrm{hr})$ for $\gamma$ was the same before and after the laboratory analysis. The mean specific activity $(\mathrm{Bq} / \mathrm{L})$ in water samples is in the order ${ }^{40} \mathrm{~K}>{ }^{232} \mathrm{Th}>{ }^{238} \mathrm{U}$. The dose rate $(\mu \mathrm{Sv} / \mathrm{hr})$ for $\gamma$ was determined before and after the analysis, the values were slightly higher before the analysis than after. No significant difference exists between the dose rate $(\mu \mathrm{sV} / \mathrm{hr})$ for $\gamma$ before and after the laboratory analysis $(\mathrm{t}$ $<0.005)$. In rock samples, the annual effective dose rate $(\mathrm{msV} / \mathrm{hr})$ radium equivalent dose for ${ }^{238} \mathrm{U}>{ }^{40} \mathrm{~K}>{ }^{232} \mathrm{Th}$. The same order was applicable to the annual effective dose (by ingestion).

Figure 1 represents the comparison of activity concentration of the three radionuclides in ores and tailings from the site considered.

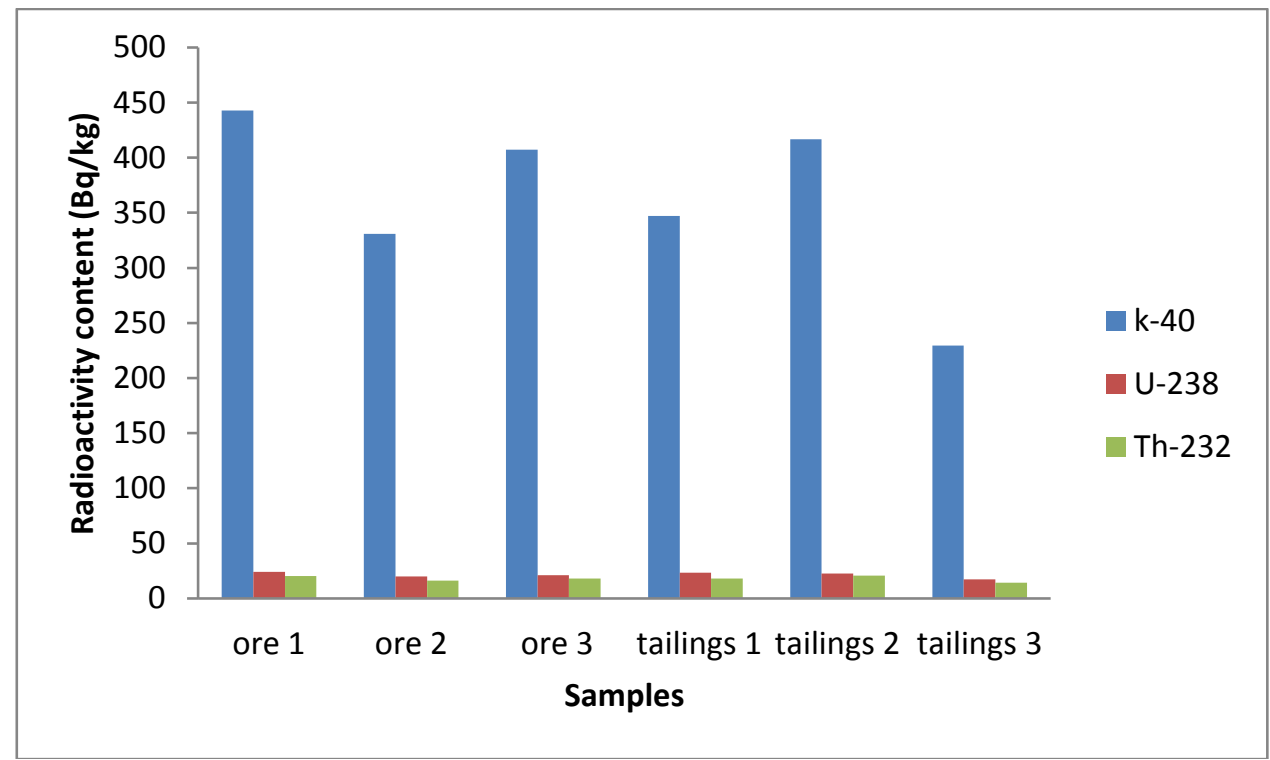

Figure 1: Activity concentration for ${ }^{238} \mathrm{U},{ }^{232} \mathrm{Th}$ and ${ }^{40} \mathrm{~K}$ in the soil samples $(\mathrm{Bq} / \mathrm{kg})$

The mean values of these naturally occurring radionuclides in ore samples were comparatively higher than their respectively tailings (except for ${ }^{40} \mathrm{~K}$ in ore 2) as shown in figure 1 above. In line with the chemical nature of the radionuclide, thorium is more abundant in the suspended load than in the bottom sediments and its transport is within particulate matter (dust) rather than by solution (Abbady, 2005) resulting in its near absolute zero detection in the product of the sedimentation zone.

In rock samples, the activity concentration for ${ }^{40} \mathrm{~K}$ was also relatively higher than ${ }^{238} \mathrm{U}$ and ${ }^{232} \mathrm{Th}$. Figure 2 represents the levels of ${ }^{40} \mathrm{~K},{ }^{238} \mathrm{U}$ and ${ }^{232} \mathrm{Th}$ in the rock samples.

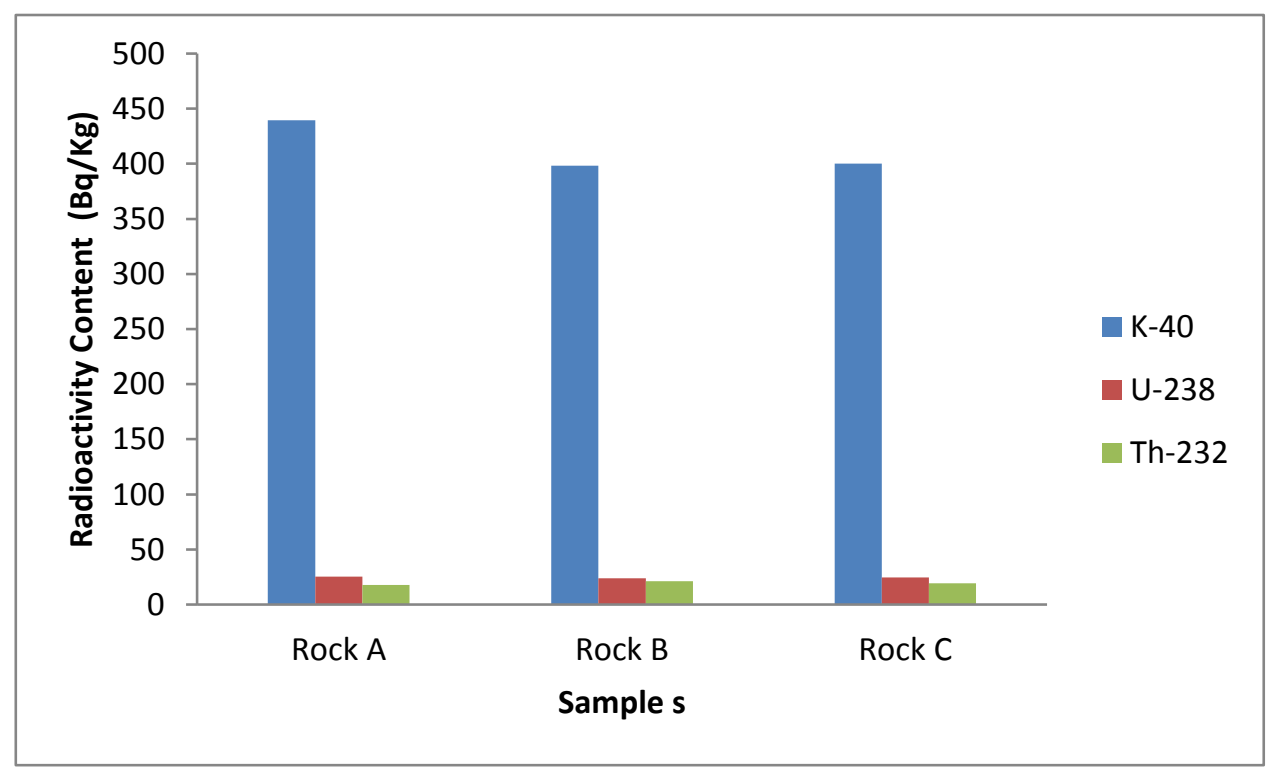

Fig 2: Activity concentration for ${ }^{40} \mathrm{~K},{ }^{238} \mathrm{U}$ and ${ }^{232} \mathrm{Th}$ in the rock samples $(\mathrm{Bq} / \mathrm{kg})$. 
${ }^{40} \mathrm{~K}$ had the highest activity concentration compared with other radionuclides. The activity concentration of ${ }^{238} \mathrm{U}$ were also relatively higher than ${ }^{232} \mathrm{Th}$. Although, these values were within the recommended limits by (UNSCEAR, 2000). The ${ }^{40} \mathrm{~K}$ activity concentration for water was distinctly higher than ${ }^{238} \mathrm{U}$ and ${ }^{232} \mathrm{Th}$ and ranged from 97.86 to $108.96 \mathrm{~Bq} / \mathrm{L}$ with a mean value of $102.44 \pm 30.50 \mathrm{~Bq} / \mathrm{L}$. For ${ }^{238} \mathrm{U}$, the specific activity ranges from 8.24 to $9.10 \mathrm{~Bq} / \mathrm{L}$ with a mean value of $8.65 \pm 4.16 \mathrm{~Bq} / \mathrm{L}$ while for ${ }^{232} \mathrm{Th}$, it was from 7.20 to $8.13 \mathrm{~Bq} / \mathrm{L}$ with the mean value of $7.71 \pm 3.42 \mathrm{~Bq} / \mathrm{L}$.

Figures 3 shows the activity concentration $(\mathrm{Bq} / \mathrm{L})$ for the three radionuclides in the water samples.

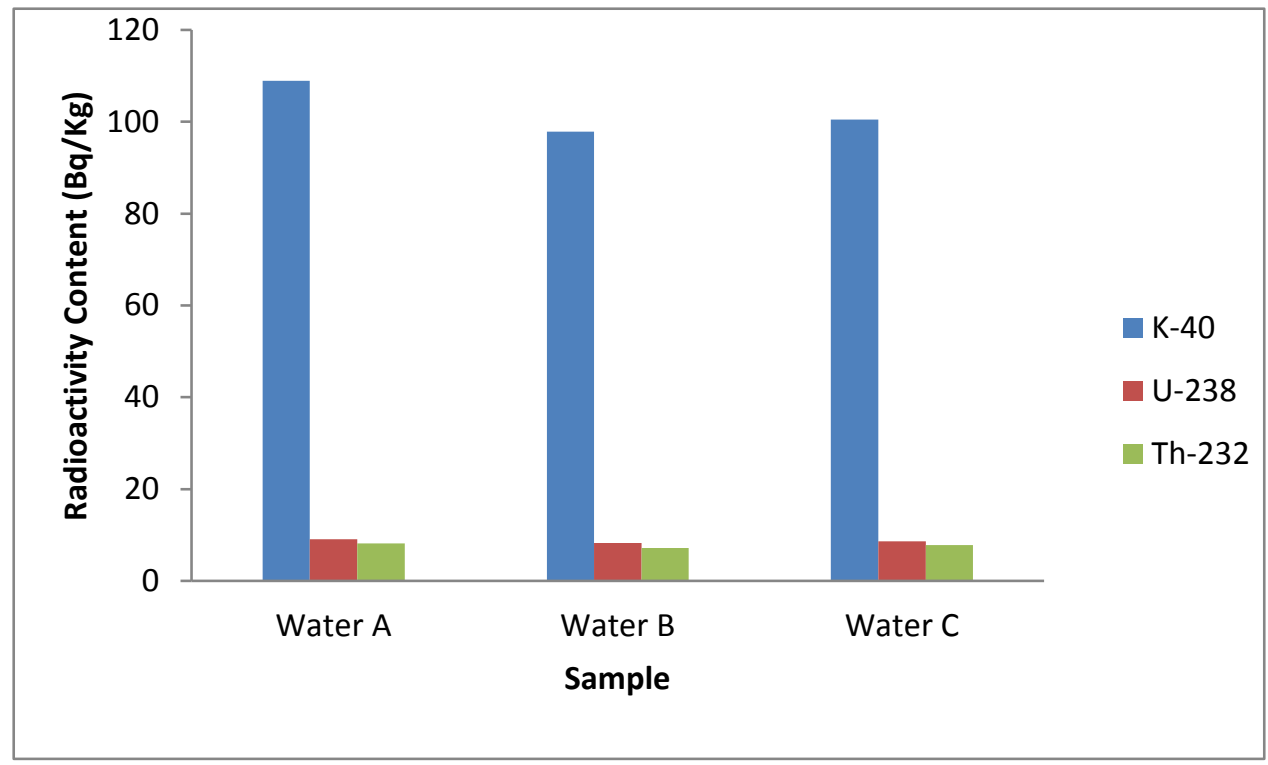

Figure 3: Activity concentration of ${ }^{238} \mathrm{U},{ }^{232} \mathrm{Th}$ and ${ }^{40} \mathrm{~K}$ in water $(\mathrm{Bq} / \mathrm{L})$

The activity concentrations of ${ }^{238} \mathrm{U},{ }^{232} \mathrm{Th}$ and ${ }^{40} \mathrm{~K}$ of all the water samples were lower than the WHO guideline value of $1.0 \mathrm{~Bq} / \mathrm{L}$ based on the World Health Organization guidelines for radionuclide intake in drinking water $(0.1 \mathrm{mSv} / \mathrm{y})$. The calculated absorbed dose rate in the soil/tailing samples ranged from 29.48 to $42.50 \mathrm{nGy} / \mathrm{h}$ with a mean value of 36.88 $\mathrm{nGy} / \mathrm{h}$ and the absorbed dose rate in rock samples from 40.27 to $41.03 \mathrm{nGy} / \mathrm{h}$ with a mean value of $40.79 \mathrm{nGy} / \mathrm{h}$. These values were comparatively higher than that of water. For water samples, the range was 13.09 to $13.89 \mathrm{nGy} / \mathrm{h}$. The absorbed dose rate observed in this study were within the worldwide range $(18-93 \mathrm{nGy} / \mathrm{h})$ while the mean absorbed dose rate was lower than the recommended limit $(59 \mathrm{nGy} / \mathrm{h})$. The Annual Effective Dose AEDR in (mSv/yr) for the soil samples varied from 0.10 to $0.21 \mathrm{mSv} \cdot \mathrm{y}^{-1}$ with the mean value $\left(0.18 \mathrm{mSv} \cdot \mathrm{y}^{-1}\right)$. For rock samples, the AEDR ranges from 0.1 to 0.20 $\mathrm{mSv} \cdot \mathrm{y}^{-1}$ with the mean value of $0.2 \mathrm{mSv} \cdot \mathrm{y}^{-1}$. These values were within the internal value $\left(1 \mathrm{mSv} \cdot \mathrm{y}^{-1}\right)$ recommended by International Commission on Radiation Protection (ICRP, 2007). The Radium equivalent dose rate ( $\mathrm{Ra}$ eq $)$ in $(\mathrm{Bq} / \mathrm{kg})$, external and internal radiation hazard index, the values of $\mathrm{Ra}_{\mathrm{eq}}$ activity in the soil samples ranged from 60.71 to 87.33 $\mathrm{Bq} / \mathrm{kg}$ with an average value of $75.94 \mathrm{~Bq} / \mathrm{kg}$ and from 83.18 to $84.35 \mathrm{~Bq} / \mathrm{kg}$ with an average value of $84.14 \mathrm{~Bq} / \mathrm{kg}$ in rock samples. The average external and internal indices were 0.205 and 0.213 respectively.

The maximum acceptable value of $\mathrm{Ra}_{\mathrm{eq}}$ in building materials must be less than $370 \mathrm{~Bq} / \mathrm{kg}$ for the material to be considered safe for use. The results showed that the $\mathrm{H}_{\text {in }}$ and $\mathrm{H}_{\mathrm{ex}}$ values for all the soil/tailing and rock samples were below unity, indicating that the radiation dose was below the permissible limit of $1 \mathrm{mSv} / \mathrm{y}$ recommended by ICRP. It also implies that the soil/tailing and rock in the study area may not pose any radiological health risk to the people using these materials for building.

The doses estimated from the investigation were below that limit $(1 \mathrm{mSv} / \mathrm{y})$ for all water samples. Water samples with the dose close or above that limit is notgood/fit for any direct purpose, it could be deposited into the soil and find its way into foods through roots.

The mean activity concentrations recorded in the present study were also compared with the World Health Organization (WHO,1996) guideline values of activity concentration for radionuclides in drinking water. The Comparison of the results obtained in the mining sites with published data from similar investigations in other parts of the country and the world average was presented in Table 4 
Table 4: Comparison of the results of the present study with similar published data

\begin{tabular}{lllll}
\hline References & Country & ${ }^{238} \mathrm{U}(\mathrm{Bq} / \mathrm{kg})$ & ${ }^{232} \mathrm{Th}(\mathrm{Bq} / \mathrm{kg})$ & ${ }^{40} \mathrm{~K}(\mathrm{~Bq} / \mathrm{kg})$ \\
\hline Present study & Nigeria & 21.4 & 17.9 & 362.4 \\
Ademola and Obed, 2012 & Nigeria & 39.8 & 17.7 & 384.2 \\
Ademola \& Ademonehin, 2010 Nigeria & 13.3 & 40.0 & 240.2 \\
Innocent et al., 2013 & Nigeria & 12.1 & 60.1 & 426.5 \\
El Afifi et al., 2006 & Egypt & 78 & 33 & 337 \\
Berekta \& Mathew, 1985 & Australia & 51.5 & 48.1 & 114.7 \\
Amrani and Tahtat, 2001 & Algeria & 41 & 27 & 422 \\
Manlanca et al., 1993 & Brazil & 61.7 & 58.5 & 564 \\
Faanu et al., 2011 & Ghana & 13.6 & 24.2 & 162.1 \\
UNSCEAR, 2000 & World Average & 35 & 30 & 420 \\
\hline
\end{tabular}

Lower activity concentration was observed by Ademola and Ademonehin (2010), Innocent et al. (2013); in Nigeria, Faanu et al (2011) in Ghana, Berekta and Mathew (1985) in Australia, Amrani and Tahbat (2001) in Algeria for ${ }^{238} \mathrm{U}$ compared with this study. In other hand, the result obtained in this study was also lower than the values reported by Ademola and Obed (2012) in Nigeria, Berekta and Mathew (1985) in Australia, Amrani and Tahbat (2001) in Algeria, Manlancaet al, (1993) in brazil and in Egypt (El Afifi et al., 2006). The average activity concentration of ${ }^{232}$ Th obtained in this study was also lower than that obtained in Nigeria by Ademola and Ademonehin (2010) as well as Innocent et al. (2013), Amrani and Tahbat (2001) in Algeria, Berekta and Mathew (1985) in Australia, El Afifi et al. (2006) in Egypt and Manlanca et al. (1993) in brazil but higher than the result obtained by Ademola and Obed (2012).

\section{CONCLUSION AND RECOMMENDATION}

In this work, the levels of radionuclides in environmental samples and the possible risks associated with the observed levels to members of the public exposed to these natural sources of radiation around the gold mines at Mokuro village in Osun State were determined. The baseline concentrations of ${ }^{238} \mathrm{U},{ }^{232} \mathrm{Th}$ and ${ }^{40} \mathrm{~K}$ in soil, rock and water samples as well as dose rate in the study area have been established using direct gamma spectroscopy. The mean activity concentrations of ${ }^{238} \mathrm{U}$, ${ }^{232} \mathrm{Th}$ and ${ }^{40} \mathrm{~K}$ in the soil and rock samples were estimated to be $21.42,17.99,362.39 \mathrm{~Bq} / \mathrm{kg}$ and $24.61,19.40,412.62 \mathrm{~Bq} / \mathrm{kg}$ respectively. For water samples, the mean activity concentrations ${ }^{238} \mathrm{U},{ }^{232} \mathrm{Th}$ and ${ }^{40} \mathrm{~K}$ were $8.65,7.71,102.44 \mathrm{~Bq} / \mathrm{L}$ respectively. The results in this study were in the same range with similar/other studies carried out in other countries and with the worldwide average activity concentrations (UNSCEAR, 2000). The potential exposure of the populace in the study area was assessed by estimating the absorbed dose rate and annual effective dose rate in soil, rock and water. The mean absorbed dose rate and the mean effective dose rates for soil were found in the range of $36.88 \mathrm{nGy} / \mathrm{h}$ and $0.180 \mathrm{mSv} / \mathrm{y}$, $40.79 \mathrm{nGy} / \mathrm{h}$ and $0.200 \mathrm{mSv} / \mathrm{y}$ for rocks and $13.34 \mathrm{nG} / \mathrm{h}$ and $0.883 \mathrm{nG} / \mathrm{h}$ for water. The absorbed dose rate obtained in this study was also lower than the worldwide mean value of $59 \mathrm{nGy} / \mathrm{h}$ as well as the mean annual effectively dose rate ( $1 \mathrm{mSv} /$ year) recommended by ICRP for public radiation exposure control.

The results indicated insignificant levels of the natural radionuclides implying that the mining activities do not pose any significant radiological hazard to the communities in this area.

However, no amount of radiation is safe because the accumulation of these doses in the study area can have adverse effect over a long period of exposure. Consequently, the radiological hazards $\left(\mathrm{Ra}_{\mathrm{eq}}\right)$ to the population in the study area were assessed based on the calculation of radium equivalent activity $\left(\mathrm{Ra}_{\mathrm{eq}}\right)$, hazard indices (external and internal) for the soil, rock and water samples. This was found to be less than the recommended maximum value $(370 \mathrm{~Bq} / \mathrm{kg})$ and the external and internal hazard indices were less than unity. Hence, the soil or rock materials in this area could be used for construction of buildings or other purposes since the activities pose no significant radiological hazards/ threat to the environment.

\section{REFERENCES}

- Abbady, A., (2005). Assessment of the natural radioactivity and its radiological hazards in some Egyptian rock phosphates. Indian Journal of pure andapplied physics. Vol.43,July 2005, pp.489-493.

- Ademola, J. A. \& Ademonehin, S. (2010). Radioactivity concentrations and dose assessment for bitumen and soil samples around bituminous deposit in Ondo state, Nigeria. Radioprotection, 45, pp. 359-368.

- Ademola, A. K., Hammed, O. S., \&Adejumobi, C. A. (2008).Radioactivity and dose assessment of marble samples from Igbeti mines, Nigeria. Radiation Protection Dosimetry, 132(1), pp 94-97. 
- Ademola, A. K., \& Obed, R. I. (2012). Gamma radioactivity levels and their corresponding external exposure of soil samples from Tantalite mining areas in Oke-Ogun, South-Western Nigeria. Radioprotection, 47, pp. $243-252$.

- Amrani, D \& Tahtat, M. (2001).Natural radioactivity I Algeria building materials. Applied Radiation and Isotopes, 54, pp. 687-689.

- Berekta, J and Mathew, P.J (1995).“ Natural Radioactivity of Australinebuldingmaterials, industrial wastes and by-products. Health Physics, 48, pp. 87-95.

- El Afifi, (2006)., Evaluation of U, Th, and emanated radon in some NORM and TENORM samples. Radiation measurements, Vol 41, pp. 627-633.

- Faanu, A., Darko, E. O., \& Ephraim, J. H. (2011).Determination of natural radioactivity and hazard in soil and rock samples in a mining area in Ghana. W. Afr. Journal of Applied Ecology, 19, pp.77-92.

- $\quad$ Ferreira da Silva, E., Zhang, C., Serrano Pinto, L., Patinha, C. \& Reis, P. (2004).Hazard Assessment of arsenic and lead in soils of Castromil gold mining area, Portugal. Applied Geochemistry, 19 (6); pp. 887-898.

- IAEA.(1996). International Basic Safety Standards for Protection against Ionising Radiation and for the safety of radiation sources, Safety Series No. 115, IAEA, Vienna.

- ICRP. (2007). 2006 recommendations of the International Commission on Radiological Protection, ICRP Publication 103, Pergamon Press, Oxford.

- Innocent, A. J., Onimisi, M. Y., \& Jonah, S. A. (2013). Evaluation of naturally occurring radionuclide materials in soil samples collected from some mining sites in Zamfara State, Nigeria. British Journal of Applied Science \&Technology, 3(4), pp. 684-692.

- Isinkaye M.O., (2013). Natural radioactivity levels and radiological health implications of tailings enriched soil and sediments around two mining sites in Southwest Nigeria. Radiaton Protection and Environment. 36 (3), pp. 122.

- $\quad$ Manlanca, A., Pessina, V., \& Dallara, G. (1993).Radionuclide content of building materials and gamma ray dose rates in dwellings of Rio-Grate-Do-Notre Brazil.Radiation Protection Dosimetry, 48, pp.199-203.

- Tchokossa, P., Olomo, J. B. and Osibote, O. A. (2006). Radioactivity in the community water supplies of IfeCentral and Ife-East local government areas of Osun State, Nigeria. Nucl.Instrum.Methods Phys. Res.A 422, pp.784-789.

- United Nations Scientific Committee on the Effects of Atomic Radiation. (2000)."Sources, effects and risks of ionization radiation", United Nations Scientific Committee on the Effects of Atomic Radiation, Report to the General assembly, with Annexes, New York.

- United Nations Scientific Committee on the Effects of Atomic Radiation (2000), Sources of Ionizing Radiation. H. Vanmarcke. SCK•CEN, Department Stralingsbeschermingsonderzoek, Boeretang 200, B-2400 Mol, België

- World Health Organisation, “Guidelines for Drinking Water Quality,” 2nd Edition, Vol. 1, 1993, pp. $114-121$. 